\title{
Global governance reforms to achieve Sustainable Development Goal One (no poverty) in BRICS
}

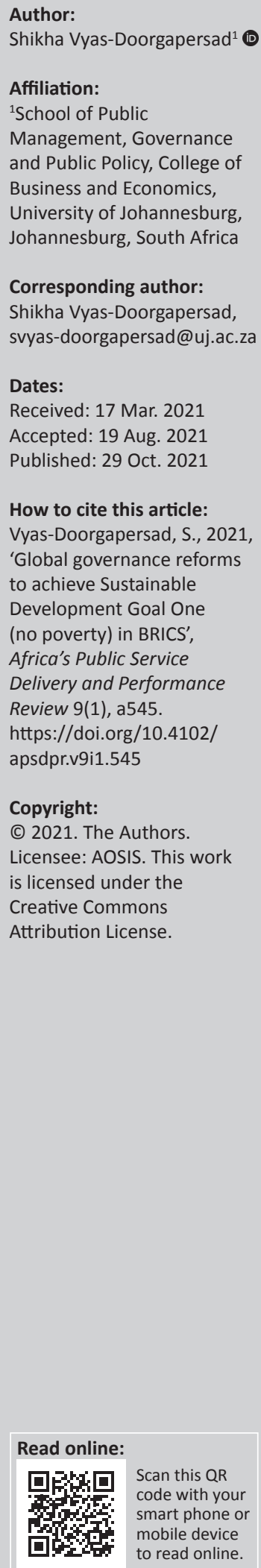

Background: The article discusses whether global governance is effective enough to uphold the economic development and can it combat poverty to achieve Sustainable Development Goal One (SDG 1) in Brazil, Russia, India, China, and South Africa (BRICS). It is an area that is least researched in the domain of global governance.

Aim: This article focuses on the SDGs as part of global goals and investigates the implementation status of SDG 1 (no poverty) in BRICS countries.

Setting: The research is descriptive in nature that played an important role in developing an in-depth account of the status of SDG 1 in BRICS.

Methods: The article employed a qualitative, descriptive research method. This article, which is theoretical in nature, drew its arguments on secondary data, which included books, journal articles, newspaper clippings, internet sources and official documents.

Results: The findings confirm that global governance cannot be successful completely until it deals with aspects of legitimacy and representation.

Conclusion: From the literature reviewed, it can be deduced that BRICS is not in a position to achieve SDG 1 on absolute terms.

Keywords: agenda 2030; governance; global governance; BRICS; poverty; sustainable development goals.

\section{Introduction}

Governance is defined as the sum of the many ways individuals and institutions, public and private, manage their common affairs (Røen 2011). Good governance includes aspects of participation, rule of law, transparency, equality, responsiveness, vision, accountability, oversight; efficiency and effectiveness and professionalism (Vyas-Doorgapersad \& Ababio 2010).

According to Komatsu (2015; also refer Vyas-Doorgapersad 2021), good governance starts with good global governance. Global governance 'encompasses activity at the international, transnational and regional levels and refers to activities in the public and private sectors that transcend national boundaries' (Benedict 2001). The Rio +20 Conference on Sustainable Development mandated countries to negotiate a universal development agenda based on three pillars of economic, social and environmental development (Merlo 2014). This article focuses on the economic pillar of the development goals linking to global governance. According to VyasDoorgapersad and Aktan (2017), globalisation, regionalisation, privatisation, deregulation are major economic change trends and these movements have resulted in significant changes in the role of the state throughout the world. It needs to be considered that even in an environment of economic interdependence, 'global economic governance may still be imperfect and, in contrast to the global economy, underdeveloped' (in Grant \& Wilson 2012).

The article employs the qualitative research approach, which is considered significant as it 'seeks to develop an in-depth understanding [and] views social phenomena holistically' (in Nyikadzino \& Vyas-Doorgapersad 2020:33).

The qualitative research approach utilises the triangulation of data (conceptual analysis, document analysis and unobtrusive research) with an aim to strengthen validity and reliability of the study. Conceptual analysis, as adapted by Nhlapo (2020), referred to the process of developing the empirical study's conceptual framework. Document analysis, as cited by Bangani and VyasDoorgapersad (2020), is an invaluable part of most schemes of triangulation. Mutenga (2021) 
stated that, unobtrusive research is non-reactive, that is, there is no direct interaction between the researcher and participants. It is a method of studying social behaviour without affecting it.

\section{Global governance and sustainable development goal one}

The 17 Sustainable Development Goals (SDGs) need 'an urgent call for action by all countries - developed and developing - in a global partnership' (United Nations [UN] 2018:1). They recognise that ending poverty and other deprivations must go hand-in-hand with strategies that improve health and education, reduce inequality and spur economic growth -whilst tackling climate change and working to preserve our oceans and forests (UN 2018). These 17 SDGs define global sustainable development priorities and aspirations for 2030 and seek to mobilise global efforts around a common set of goals and targets. The SDGs call for worldwide action amongst governments, business and civil society to end poverty and create a life of dignity and opportunity for all, within the boundaries of the planet (SDG Compass 2015). This article focuses on SDG 1 linking to global (economic) reforms as poverty reduction is the number one priority in the UN list of SDGs that needs to be achieved by governments globally. The UN has defined 7 targets and 14 indicators for SDG 1 that are available on SDG Tracker website (2018), which also highlights the situation of SDG 1 stating that, one-in-five people in developing regions still live on less than $\$ 1.90$ a day. Millions more make little more than this daily amount. It needs to be considered that in terms of global governance, as highlighted by World Vision (2020), by 2030, as part of the UN SDGs, global leaders aim to eradicate extreme poverty for all people everywhere.

Sustainable Development Goal One is linked to poverty reduction. This 'concept of poverty is only applied to humans in everyday language and is an evaluative concept used by human societies to set minimum standards for those aspects of human lifestyles acquirable through economic capacities' (Lotter 2007:1201-1202). The economic capabilities are not enough for human beings to live a life with acceptable standards of services. This is reflected in the report of the UN SDG Knowledge Platform (2020), which emphasised that the world is not on track to achieve the target of less than $3 \%$ of the world living in extreme poverty by 2030 . The statement can be substantiated with the global statistics of poverty compiled by World Vision (2020) highlighting that:

\footnotetext{
.. 736 million people live in extreme poverty, surviving on less than $\$ 1.90$ a day; and by 2030 , an estimated $80 \%$ of the world's extreme poor will live in fragile contexts. (p. 1)
}

Economic development is not possible in regions experiencing extreme poverty, hence global leaders come together to offer financial aid. In order to achieve SDG 1, Ugoani (2015) suggested that the international community needs to grapple with much more than financial governance issues. There is need for transformational public policy strategies that seek to determine whose welfare, which right and what goals matter most (Ugoani 2015). This makes global governance - whether it pertains to finance, trade, the environment, education, transportation or health etc. - one of the most vital and difficult challenges of the modern world (Ugoani 2015). The article stresses that poverty is a global issue that needs to be supported with global governance in the form of international cooperation and multilateral institutions, which need to work with governments, private sector, non-profit organisations, etc. to achieve the SDG 1.

Brazil, Russia, India, China and South Africa are considered as a case under study. Since its inception in 2009, the BRIC(S) grouping has grown in stature internationally. South Africa joined BRIC in 2010, becoming the fifth member of this bloc, hence the acronym BRICS. The BRICS countries have met annually to enhance cooperation amongst themselves and discuss issues of common concern, including global governance reforms (Pelchem 2021) and socio-economic development challenges.

BRICS, global governance and sustainable development goal one: A nexus

The concept global governance reform, initially referred to as a radical restructuring of the global economic order, is nowadays used as a reformist concept that seeks to accommodate the interests of neo-liberal globalisation with relatively marginal reforms that are seen as necessary to keep the system running (Overbeek et al. 2010). Moreover, the concept is analytically misleading given the rise of traditional forms of interstate bargaining that followed both the global financial crisis and the rise of the BRICS states (Overbeek et al. 2010). The following sections discuss a nexus between SDG 1, global governance and BRICS.

\section{Brazil}

According to the Index of Economic Freedom, an annual index and ranking published by the Heritage Foundation, Brazil's economic freedom score is 53.7, making its economy the 144th freest in the 2020 Index. Its overall score has increased by 1.8 points, led by dramatic increases in scores for government integrity and investment freedom (The Heritage Foundation 2020a). In addition, the path of industrialisation and the adoption of an agricultural production model marked by wealth concentration and low demand of labour force were key factors for the urbanisation of the country, a phenomenon directly related to the demographic transition in Brazil (Anderson, Das \& Schneider 2014). The country's growth rate has been declining from an annual growth rate of $4.5 \%$ (between 2006 and 2010) to $2.1 \%$ (between 2011 and 2014). There was a significant contraction in economic activity in 2015 and 2016, with the gross domestic product (GDP) dropping by $3.6 \%$ and $3.4 \%$, respectively (World Bank 2020). A reason could be the lack of fiscal and financial sustainability in the country. 
However, Brazil's economy, according to the statistics published by the Heritage Foundation (2020a:1), 'recovered from the deep 2015 to 2016 recession and achieved GDP growth of slightly more than $1 \%$ in $2018^{\prime}$. Despite the growth seen in the GDP, the poverty levels in the country still yields negative socio-economic development. According to Douglas (2018), almost 55 million Brazilians were living in poverty in 2017, an increase of 2 million since 2016... The number is equivalent to $26.5 \%$ of Brazil's total population and marks a $4 \%$ rise in 1 year. It was further stated by Douglas (2018) that 54.8 million Brazilians are defined as poor by World Bank criteria and extreme poverty also rose to reach $7.4 \%$ of the total population.

At the country level, the Government of Brazil has decided to create a National Commission for the Sustainable Development Goals, the main institutional governance mechanism for fostering dialogue, engagement and integration of the initiatives carried out by subnational entities and civil society. The aim of the commission is to internalise, disseminate and ensure the transparency of the 2030 Agenda implementation process (UN 2017). Therefore, it can be deduced that the creation of the National Commission for the Sustainable Development Goals is a government initiative where inter-ministerial committees are responsible to assess the implementation of SDGs in country-specific context. Brazil is dealing with its challenges with regard to SDG 1 at intra-governmental levels. In addition, Anderson et al. (2014) highlighted that the global economic crisis of 2008 stirred up a number of measures by the Brazilian government, which both reduced the effects of the crisis upon the country and contributed to its economic growth. The core guideline of Brazilian strategy to handle the crisis and keep the economy heated up was investing, once again, to expand its domestic market. This strategy is believed to be significant in enhancing the role of the state.

In terms of global governance, Brazil is listed as a partner in the Partnerships for SDGs online platform. The platform is UN global registry of voluntary commitments and multistakeholder partnerships made in support of sustainable development and the 17 SDGs. The platform also facilitates the sharing knowledge and expertise amongst multistakeholder SDG-related partnerships and voluntary commitments and for providing periodic updates on their progress (UN 2017). It is a challenging reality that the platform, under 'Partnerships and Commitments' do not discuss any form of partnership to deal with SDG 1 in Brazil. This has negatively impacted the country to achieve its global development goal as highlighted by Scott et al. (2017):

Brazil, however, is not forecast to meet a number of SDG targets by 2030 . For instance, by 2030 an estimated 7.6 percent of the population might well still be living in poverty on less than $\$ 3.10$ per day (SDG 1). (p. 3)

This situation defies the notion of global governance.
Brazilian President Lula da Silva has envisioned the need of global economic governance reforms, hence emphasised that (South African Institute of International Affairs [SAIIA] 2007):

[R]eform of global finance institutions (WB and IMF) [is] critical. He warned that emerging countries would look elsewhere for funding support should existing power relations continue unchanged. The future relevance of the current global economic governance architecture will depend on whether these global institutions become more inclusive and efficient. (p. 1)

Brazil, nonetheless, is not in a favourable position to achieve its SDGs.

According to Social Watch (2020), this situation is a consequence of the lack of the necessary budgetary allocations, resulting from the current austerity policies of the Temer administration. Such policies establish a cap for social expenses and promote budgetary cuts of over $50 \%$ in many governmental bodies, along with other reforms that lead to social exclusion, increase inequalities and relinquish the national wealth via privatisation processes.

\section{Russia}

Russia faced relatively tight monetary policy in the first half of 2019, in addition weak real disposable-income dynamics because of higher inflation on the back of rate hike in the Value Added Tax (VAT) and a slow start in the implementation of national projects dampened growth in 2019. A decline in the labour force and in the number of employed people, because of population ageing, continues to be a drag and has not been yet compensated by the recently increased retirement age (World Bank 2019a). These factors may be considered as domestic challenges leading to poverty in the country:

The $[P]$ overty headcount increased in the first two quarters of 2019 by 0.2 percentage points compared to the same period of 2018. The number of poor people increased by 0.2 million to 19.8 million. The increase was mainly driven by a contraction of real disposable income at the bottom of the distribution as well as a raising of the poverty line in real terms. (World Bank 2019a:1)

The government hopes to reduce the share of Russians living in poverty - defined as those with a monthly income below $\$ 180$ to $10.8 \%$, an upgrade on its previous target for 2020 of $11.7 \%$. In absolute terms that would represent around 16 million Russians living below the threshold (The Moscow Times 2020). However, according to reports published in the Moscow Times (2020), the number of Russians living in poverty is still well off the government's target and is heading southward. The state statistics agency Rosstat stated that 19.2 million Russians were living in poverty as of September 2019 - a slight increase on the number recorded 1 year earlier.

This situation also has a negative impact on the implementation of SDG 1 in Russia. According to Kolmar and Sakharov (2019:191), 'since the adoption of the SDGs, Russia has not laid out a national approach to their 
implementation and has not formulated an adapted national strategy of sustainable development'. In order to meet the global demands regarding achievement of global development goals in Russia, the Presidential Address to the Federal Assembly in 2018 discussed issues related to:

$[H]$ ealthcare, education, demography, commodities and urban areas, international cooperation and export, labour productivity, SMEs and promotion of private entrepreneurship, safe and quality infrastructure, ecology and digital economy - all of which correlate with the SDGs and thus should be incorporated into strategic plans. (Kolmar \& Sakharov 2019:193)

The action plans lack the discussion on poverty reduction, hence neglecting the fact that globalisation cannot be sustainable until challenges are resolved in a localised context.

This realisation later led to the inclusion of SDG 1 in the Russia's State Programmes in 2018 to implement measures such as employment, social grants, etc. However, target $1 \mathrm{~B}$ of SDG 1 that aims to 'create sound policy frameworks at the national, regional and international levels, based on pro-poor and gender-sensitive development strategies to support accelerated investment in poverty eradication actions' (UN 2018:3) is not covered under the poverty reduction measures and related programmes. This raises concerns regarding the good governance at national level and global governance at international level.

This is worth noting that in terms of global governance, Russia had to face 'sanctions, imposed by the United States (US), European Union (EU) and other countries in various tranches since 2014, [which] include travel bans for prominent individuals, prohibit long-term financing for some major corporates and ban assistance to Russian oil and gas companies for Arctic, shale and offshore projects' (Foy 2020:1) hence negatively impacting economic growth. Foy (2020) further highlighted that targeted sanctions have also had an undeniable impact. The US' imposition of personal sanctions on Oleg Deripaska and some other leading businessmen in 2018 effectively cut all of their companies off from the global market, hitting some of Russia's most important industrial groups. A report entitled 'Weaker Global Outlook Sharpens Focus on Domestic Reforms' by World Bank (2019b) added that:

$[D]$ ownside risks to the global growth forecast prevail in view of a weaker global economy, rising trade tensions, and domestic factors. Should an adverse shock materialise to the global economy, this could spill over into Russia through trade, financial, and commodity market channels. Russia also remains exposed to the possibility of additional economic sanctions, which would further dampen domestic and foreign private investment. (p. 1)

The country has to find intra-governmental resources to deal with fiscal challenges. However, 'some observers place the blame on Western economic sanctions, which have contributed to Russian poverty and economic uncertainty' (Evans 2019:2). This raises question regarding the implementation of global governance in such a context. As for Brazil, the Russia is also a partner in the Partnerships for SDGs online platform. The same challenging reality is witnessed in Russia also that the platform under 'Partnerships and Commitments' (UN 2020) does not discuss any form of partnership to deal with SDG 1 in Russia.

\section{India}

India is the world's fourth-largest economy. It produced $\$ 9.4$ trillion in goods and services in 2017 (The Balance 2020). The richest $10 \%$ in India controls $80 \%$ of the nation's wealth, according to a 2017 report published by Oxfam, an international confederation of agencies fighting poverty. And the top $1 \%$ owns $58 \%$ of India's wealth (by comparison, the richest $1 \%$ in the US owns 37\% of the wealth) (Basu 2017). On the other hand:

About $60 \%$ of India's nearly 1.3 billion people live on less than $\$ 3.10$ a day, the World Bank's median poverty line. And 21\%, or more than 250 million people, survive on less than $\$ 2$ a day. (Basu 2017:1)

This situation can be considered as a wealth-divide that leads to economic inequalities in the country. Despite of wealth availability in the country because of internal politicised strategies, India is facing a downhill scenario in terms of sustaining its economic status whereby:

$[N]$ ominal GDP growth rate is at 42 -year low. Nominal GDP growth rate is considered a closer reflection of actual status of economic progress as it is the market value of goods and services produced without being adjusted for inflation. At 7.5 per cent in 2019-20, nominal GDP is expected to be worst since 1978 and far below than government's earlier projection of 12 per cent. (Dutta 2020:1)

This economic situation could affect the effective realisation of SDG 1 in India, therefore the government has launched 'many progressive schemes, including the world's largest employment guarantee scheme, the Mahatma Gandhi National Rural Employment Guarantee Scheme and the National Social Assistance Programme' (UN India 2020:1).

Nonetheless, traditionally disadvantaged subgroups such as rural dwellers, scheduled castes and scheduled tribes, Muslims and young children were still the poorest in 2015-2016 (UN India 2020). The reason poverty still prevails in these segments is that India faces enormous challenges of significant regional and social disparities in poverty, and in achieving improvement in quality of employment and education particularly for the poor, and efficient social protection programmes along with gender empowerment (Dev 2017). The SDG 1 measures are not absolute as nearly half $(47.9 \%)$ of the Indian households that have more than five children are severely deprived of shelter, water, sanitation, health and education as compared with $7.8 \%$ of poor families without children, according to the latest Indian Human Development Survey released on 11 May 2019 (Ali 2019). India requires assistance at both central and state levels 
to establish financial strategies dealing with poverty. This is happening but at a very slow pace. The reason could be internal politics whereby:

Modi is up against India's bloated government bureaucracy. That makes the execution of any fiscal or monetary policy difficult. In August 2015, he was blocked from passing a bill to acquire land to promote infrastructure. (The Balance 2020:4)

This economic scenario may negatively impact the implementation of SDG 1. In terms of global governance, 'investors backed off from India and other emerging markets when the U.S. Federal Reserve began tapering its quantitative easing programme' (The Balance 2020:4), which negatively impacted the currencies of the emerging markets, including India.

\section{China}

The Chinese economy has experienced unprecedented growth in the last few decades that catapulted the country to becoming the world's second largest economy. In 1978 when China started the programme of economic reforms the country ranked ninth in nominal GDP with USD 214 billion; 35 years later it jumped up to second place with a nominal GDP of USD 9.2 trillion (Focus Economics 2020). This situation did not improve upon the statistics of poverty in the country:

In as recent as 2015, there were 55 million poor people in rural areas. The World Bank explains that because of China's fastgrowing economy, it has brought on challenges such as high inequality, environmental sustainability issues and poverty. Thankfully, China is aware of these problems and works to eradicate poverty within its walls. (The Borgen Project 2018:1)

However, towards the end of 2016, China still had 43.35 million people under the poverty line of 2300 yuan (about \$334) in annual income. With so many loans taken out for poverty assistance, Chinese debt in 2000 to 2014 rose from $\$ 2.1$ trillion to $\$ 28.2$ trillion. This amount is projected to increase by around 300\% of GDP by the year 2022 (The Borgen Project 2018:2).

The IMF in a recent study stated that from the first economic reforms of the 1970s through 2002, poverty persisted because of a decrease in the 'quality of the economic growth' paired with more inequality (Forbes Media 2020). The assessment of economic reforms and measures undertaken allowed the government to divert fiscal spending towards achieving SDG 1 through anti-poverty programmes such as building houses and roads, especially in rural areas:

The Chinese government spent 920 million yuan (\$146000) every year from 1994 to 2000 on highways in 529 poor counties in 21 provinces, for example. A similar road construction programme begun in 2002 was set at 31 billion yuan, 16.7 billion invested by the central government and 14.3 billion by local governments. Stimulus for job creation during economic downturn in 2008 also came from government funds. (Forbes Media 2020:3)
The success of such measures will only be assessed in coming years.

\section{South Africa}

The South African Population in 2020 was 59136154 (World Population Review 2020). The statistics reveal that more than half of South Africans (55.5\%) or 30-million people live below the national poverty line of R992 per month. This number has increased since 2011. The increase was confirmed by a report published by the United Nations Development Programme (UNDP) ([2014] cited in Vyas-Doorgapersad 2018:121) highlighting that 'the population of South Africa is 51.8 million with a poverty rate of $23 \%$.' When looking at the poverty headcount by sex using the upper-bound poverty line (UBPL), adult males and females experienced a headcount of $46.1 \%$ and $52.0 \%$, respectively. Adult females experienced higher levels of poverty when compared with their male counterparts, regardless of the poverty line used. Stats SA's Poverty Trends in South Africa report, released in August 2017 (Africa Check 2020), showed that a quarter of the population lived in extreme poverty in 2015. More than half the population (56\%) was considered to be living in poverty as defined by the UBPL. Furthermore, 'there is a high level of unemployment $(25 \%)$, especially amongst young people (15-35 years of age), which stands at $34.5 \%$ ', as cited by Vyas-Doorgapersad (2018:121). Policy uncertainty, weaknesses in regulatory oversight, violent crime, labour unrest and unprofitable state-owned enterprises have a negative effect on business activity. Labour market rigidity has contributed to extremely high unemployment rates (The Heritage Foundation 2020b). Ngonyama (2013:5) stated his concern that 'despite positive economic growth, which is central to financing development programmes, the triple challenges of unemployment, poverty and inequality remain the main development challenges facing South Africa. It is therefore not surprising that [25] years after the abolition of apartheid, the geographical, racial and gender composition of poverty still reflects past imbalance'. As a result of its internal challenges responsible for poverty, South Africa, according to the UNDP (2012 cited in Vyas-Doorgapersad 2018):

[I]s ranked 123 out of 187 on the Human Development Index. It goes on to state that the country has significant disparities in levels of relative poverty across provinces and that inequality is very evident with an essentially static Gini coefficient above 0.7 . (p. 121)

The South African Government has invested in entrepreneurship, education and agriculture interventions to combat poverty. There are national policies and programmes in place to achieve the SDG 1, such as the National Development Plan 2012 to reduce poverty and inequality by 2030.

In terms of global governance, Ngonyama (2013:8) cites that 'socio-political conditions linked to global politics drive the current socio-economic situation in developing countries such as South Africa. As a member of the World 
Trade Organization (WTO), South Africa is not only interested in building its national economy but also has to compete at a global level'. In this context, Ngonyama (2013) further highlighted that measures of development are largely based on quantitative indicators, hiding deep inequalities that exist between poor communities and more affluent areas. However, the inequalities that exist between nations on a global scale are also reproduced within national boundaries. Hence, poor communities have not received any tangible benefits from current economic growth.

\section{Challenges related to BRICS to be part of global governance and achieve sustainable development goal one}

Merlo (2014) highlighted in his study that in addition to a well-established commitment by the G77 + China to national sovereignty and to poverty eradication, the BRICS placed a particular emphasis on two new principles for global development that are universal and common but differentiated responsibilities (CBDR) (Merlo 2014). These aims may be achieved through joint declarations and multinational partnerships with other countries.

In terms of economic status, 'fragile-five' was a term coined by Morgan Stanley in its report in a 2013 to describe the status of economy in five of the emerging markets. They were Brazil, India, Indonesia, South Africa and Turkey (Dutta 2020). With Indian economy facing another downturn and apparently more serious than the previous one, there are talks about India slipping back in the club of so-called fragile five (Dutta 2020). A common lesson that BRICS can learn from each other is the adoption of strategies that are showing success. For example, in Brazil:

[T] he social cash transfer programme introduced by President Lula da Silva in 2003 demonstrated the highest efficiency: 'Bolsa Família' aimed at the poor population and 'Benefício de Prestação Continuada' focused on the elderly population and people with disabilities. The 'Bolsa Família' programme became the largest scheme for social cash transfers in the world and a major source of income for the poor of Brazil. (Massarova \& Potapenko 2018:189)

Rapid growth, as stated in the UN document (2017) is the key weapon in any country's arsenal to combat poverty. On the one hand, it creates well-paid jobs, which place necessary purchasing power in the hands of households to access food, clothing, housing, education and health. On the other, it brings ever-rising revenues to the government to finance social spending (UN 2017). In addition, 'a relatively egalitarian growth path; increases in agricultural productivity that help raise wages and keep food prices under control; expansion of non-agricultural employment, including in rural areas; and direct public action in the form of poverty eradication programmes' (Ghosh 2010:22) are also contributing towards achieving SDG 1.
In case of Russia, welfare improvement including poverty reduction are the priority directions of the social policy and they are defined in the 'Concept of Long-term Socioeconomic Development of the Russian Federation 2020' and the 'National Security Concept of the Russian Federation'. The main measures for reducing the poverty rate are also determined in the government programme 'Social Support of Citizens' aimed at ensuring accessibility, high quality and security of social services (Massarova \& Potapenko 2018).

China has been driving international development with its practical approach to poverty reduction and development and pushing for the establishment of a new type of international exchanges and cooperation for poverty reduction with winwin cooperation as the core (Weiping 2018). In South Africa, the Government introduced Reconstruction and Development Programme (RDP); Growth, Employment and Redistribution (GEAR); Accelerated and shared Growth Initiative (AcSGI); and Extended Public Works Programme (EPWP), with an aim of reducing poverty in the country. India has adopted the rapid growth strategy as part of economic reforms and hence is showing a decline in poverty. The BRICS need to learn from each other and apply strategies for achieving good economic governance required for the realisation of SDG 1.

A hope lies in the fact that at the 2016 G20 Hangzhou Summit, an action plan was developed, for the first time ever, to implement the 2030 Agenda. At the Belt and Road Forum for International Cooperation in May 2017, heads of state and government of 29 countries and over 1600 representatives from more than 140 countries and 80 international organisations put forward the initiative to jointly build the Belt and Road, so as to establish a new platform for win-win cooperation and create new opportunities for implementing the Agenda (Weiping 2018), hence enhancing global governance. According to the World Bank (2016), the Global Poverty Reduction and Inclusive Growth (GPIG) Portal was officially launched in Beijing on 8 May 2016, dedicated to sharing best practices and tools for poverty reduction in China, Asia and the world. As the first online platform in China focusing on poverty reduction worldwide, it offers information on the latest research in poverty reduction and inclusive growth, including experts' opinions, events, trends and opportunities.

Another emerging challenge is the spread of the coronavirus disease (COVID-19). The influence of BRICS countries in the international arena has risen enormously in recent decades. However, little attention has been paid to the comparison of COVID-19 pandemic responses and related factors in BRICS countries, despite their increasing global significance as individual countries and as an economic grouping (Zhu et al. 2021). The economic and social impact of COVID-19 is severe for the BRICS countries. In this scenario, these countries need to concentrate on steering their domestic economies out of this pandemic crisis (Dash, Sethi \& Dash 2020). 


\section{Conclusion}

From the literature review stated here, it can be deduced that BRICS is not in a position to achieve SDG 1 in absolute terms. It can be deduced further that not all BRICS Summits discussed the need to eradicate poverty as much of the focus was on other SDGs.

When the first BRICS Summit was held in China (2011), the international community was already aware that the UN Millennium Campaign (2000-2015) was about to reach limited achievements. Whilst being the most successful antipoverty effort in the history of humankind, the 8 Millennium Development Goals (MDGs) and the 21 Targets were not fully reached, and the agenda was left unfinished for millions of people in the most disadvantageous countries. In the UN Summit in New York (2015), it was established that this partial success was to be addressed by means of the 2030 Agenda, which included the SDGs: a new set of 17 Goals and 169 Targets to be reached in 15 years to enhance the transition to sustainable development and to end poverty in all forms, everywhere and forever (Nkibrics.ru. 2019). However, BRICS is also not achieving all SDGs as the priorities are different. For example, a study conducted by Ali et al. (2018) highlighted country-wise the most adopted UN SDGs goals as follows:

- Brazil, 'Decent Work and Economic Growth' (23\%) and 'Peace, Justice and Strong Institutions' (22\%);

- Russia, 'Decent Work and Economic Growth'(18\%) and 'Peace, Justice and Strong Institutions' (15\%);

- India, 'Decent Work and Economic Growth'(18\%), 'Peace, Justice and Strong Institutions' (15\%) and 'Industry, Innovation and Infrastructure' (30\%);

- China, 'Industry Innovation and Infrastructure' (20\%) and 'Decent Work and Economic Growth' (19\%);

- South Africa, 'Peace, Justice and Strong Institutions' (21\%) and 'Decent Work and Economic Growth' (18\%).

The empirical data confirms that there is more focus on three SDGs that are 'Peace, Justice and Strong Institutions', 'Decent Work and Economic Growth' and 'Industry Innovation and Infrastructure' and there is a lack of consideration to work on SDG 1.

The declarations of BRICS summit also lack the SDG 1 targets to achieve with inadequate focus on what, how and when poverty reduction measures will be implemented. This is substantiated by the documentary analysis of BRICS summits. The third BRICS Summit held in 2011 in Sanya, China stated:

[I]s the first to include South Africa. The Sanya Declaration is also the first to incorporate Action Plans and new areas of cooperation. The declaration states that 'eradication of extreme poverty and hunger is a moral, social, political and economic imperative of humankind and one of the greatest global challenges in the world today'. (De Vasconcelos Costa Lobato 2018:3)
The declaration of the fourth BRICS Summit, held in New Delhi, India, in 2012, highlighted the group's concern about the unstable situation of the world market and the stability policies adopted by central countries that adversely affect emerging countries. Concerning the social issue, the group reiterated the aspects of sustainable growth and development associated with food safety, eradication of poverty, hunger and malnutrition and the urgent need to create jobs to improve the standard of living in the world (De Vasconcelos Costa Lobato 2018). The fifth BRICS Summit was held in Durban, South Africa in March 2013. The summit resulted in the eThekwini Declaration.

The economic crisis takes on much of the points in the declaration, where the group again criticised the measures taken by the central countries to protect their economies, with negative impacts in other countries, especially the increasing internal debts and rising unemployment, maintaining world instability. In the declaration, BRICS announced its most daring initiative, which was the decision to create the New Development Bank (NDB), the BRICS bank (De Vasconcelos Costa Lobato 2018).

The sixth BRICS summit was held in Fortaleza, Brazil, in 2014. The central theme being 'Inclusive growth: sustainable solutions' with the objective of maintaining inclusive macroeconomic and social policies ... and facing the challenges posed by the need to simultaneously achieve growth, inclusion, protection and preservation (De Vasconcelos Costa Lobato 2018). The review of discussions during these summits confirmed that the eradication of poverty remains a central theme, but without specific intraBRICS proposals. It is instead the core of an intergovernmental process of building an integrated universal development agenda (De Vasconcelos Costa Lobato 2018), hence it lacks the essence of good global governance seeking inter-regional cooperation amongst member states.

In order to meet with the SDG 1, the leaders of BRICS have taken strategic decisions to eradicate poverty, such as, the Former Brazilian President Michel Termer who aimed to secure more foreign investment; Russia and India boosted investment in an integrated manner; China pledged \$76.4 million for a BRICS economic and technology cooperation agenda. President $\mathrm{Xi}$ Jinping also pledged $\$ 4$ million to the NDB; and South African Former President, Jacob Zuma, focused on the implementation of the UN's SDGs 2030 to eradicate poverty (The Borgen Project 2020). However, the implementation strategies are not discussed in detail as when the measures will be adopted and how the measures will be evaluated.

The lack of monitoring and evaluation of SDG 1 and related targets may be a stumbling block for BRICS to realise its aim of poverty eradication.

In 2020, the world globally started experiencing the dilemma of COVID-19. The difference between opinions is 
already witnessed amongst EU; the US, being a highly resourceful nation is struggling internally to strategies and operationalise health system and the emerging economies are facing economic shut down. The situation is dire for people living in poverty and unemployment rate has drastically increased because of the pandemic. In this scenario, the questions that emerge include: Do BRICS have economic resources to bring financial stability and fiscal strengthening to its own member states? and Can BRICS also assist member states to bring economic viability despite financial struggle within their own countries in a postCOVID-19 era?

This aspect of global governance will only be observed in the coming years.

The article is an effort to discuss these aspects conceptually explaining the meaning of global governance and contextually its applicability in BRICS emphasising its relevance to global development goals. The suggestions can be applicable globally, based on the economic development and resource advancement in country-specific contexts.

\section{Acknowledgements}

The author would like to acknowledge the works of scholars who have contributed their knowledge debating the aspects of service delivery in South Africa.

\section{Competing interests}

The author declares that there is no financial or personal relationship that may have inappropriately influenced him in writing this article.

\section{Author's contributions}

I declare that I am the sole author of this research article.

\section{Ethical considerations}

This article followed all ethical standards for research without direct contact with human or animal subjects.

\section{Funding information}

This study received no specific grant from any funding agency in the public, commercial or not-for-profit sectors.

\section{Data availability}

Data sharing is not appropriate to this article as no new data were created in this study.

\section{Disclaimer}

The views and opinions expressed in this article are those of the author and do not necessarily reflect the official policy or position of any affiliated agency of the author, and the Publisher/s.

\section{References}

Africa Check, 2020, Frequently asked questions about poverty in South Africa, viewed 02 April 2020, from https://africacheck.org/factsheets/frequently-askedquestions-about-poverty-in-south-africa/.

Ali, S., 2019, 3 times higher poverty rates in Indian households with children: Survey, viewed 23 March 2020, from https://www.business-standard.com/article/ current-affairs/3-times-higher-poverty-rates-in-indian-households-with-childrensurvey-119070900133_1.html.

Ali, S., Hussain, T., Zhang, G., Nurunnabi, M. \& Li, B., 2018, 'The implementation of sustainable development goals in "BRICS" countries', Sustainability 10(7), 2513. https://doi.org/10.3390/su10072513

Anderson, J.S. Das, N. \& Schneider, S., 2014, Brazilian demographic transition and the strategic role of youth, viewed 21 March 2020, from https://journals.openedition. org/eps/5774?lang=en

Bangani, A. \& Vyas-Doorgapersad, S., 2020, 'The implementation of gender equality within the South African public service', Africa's Public Service Delivery \& Performance Review 8(1), a353. https://doi.org/10.4102/apsdpr.v8i1.353

Basu, M., 2017, Seeing the New India through the eyes of an invisible woman, viewed 07 April 2020, from https://edition.cnn.com/interactive/2017/10/world/i-onindia-income-gap/.

Benedict, K., 2001, Global governance, viewed 07 April 2020, from https://www. sciencedirect.com/science/article/pii/B0080430767044995.

Dash, D.P., Sethi, N. \& Dash, A.K., 2020, Infectious disease, human capital, and the BRICS economy in the time of COVID-19, viewed 13 July 2021, from https://www. sciencedirect.com/science/article/pii/S2215016120304222.

De Vasconcelos Costa Lobato, L., 2018, The social issue in the BRICS project, viewed 26 March 2020, from http://www.scielo.br/scielo.php?pid=\$1413-812320180 $00702133 \&$ script $=$ sci_arttext\&tlng $=$ en.

Dev, S.M., 2017, SDG goal 1 on poverty: Challenges for India, viewed 23 March 2020, from http://www.businessworld.in/article/SDG-Goal-1-On-Poverty-ChallengesFor-India/06-02-2017-112492/.

Douglas, B., 2018, Number of Brazilians living in poverty rises 2 million in a year, viewed 20 March 2020, from https://www.bloomberg.com/news/.

Dutta, P.K., 2020, Slowdown blues: State of Indian economy and its fragile-five past, viewed 20 March 2020, from https://www.indiatoday.in/news-analysis/story/ slowdown-blues-state-of-indian-economy-and-its-fragile-fivepast-1635328-2020-01-09.

Evans, P., 2019, 13 mind-blowing facts about Russia's economy, viewed 03 April 2020, from https://markets.businessinsider.com/news/stocks/russia-economyfacts-2019-4-1028116037.

Focus Economics, 2020, China economic outlook, Focus Economics, Barcelona.

Forbes Media, 2020, Despite China's fast-growing wealth, millions still remain poor, viewed 18 March 2020, from https://www forbes.com/sites/forbes-personalshopper/2020/03/24/9-of-the-best-running-strollers-for-2020/\#427536dd4443.

Foy, H., 2020, Russia: Adapting to sanctions leaves economy in Robust health, viewed 05 March 2020, from https://www.ft.com/content/a9b982e6-169a-11ea-b8690971bffac109.

Ghosh, J., 2010, Poverty reduction in China and India: Policy implications of recent trends, viewed 10 March 2020, from https://www.un.org/esa/desa/papers/2010/ wp92_2010.pdf.

Grant, W. \& Wilson, G.K., 2012, The consequences of the global financial crisis: The rhetoric of reform and regulation, viewed 02 April 2020, from https://www. oxfordscholarship.com/view/10.1093/acprof:oso/9780199641987.001.0001/ acprof-9780199641987.

Kolmar, O. \& Sakharov, A., 2019, 'Prospects of implementation of the UN SDG in Russia', International Organisations Research Journal 14(1), 189-206. https://doi. org/10.17323/1996-7845-2019-01-11

Komatsu, T., 2015, Good governance starts with good global governance, viewed 02 April 2020, from https://berkleycenter.georgetown.edu/responses/goodgovernance-starts-with-good-global-governance.

Lötter, H., 2007, 'Defining poverty as distinctively human', HTS Teologiese Studies/ Theological Studies 63(3), 1195-1212. https://doi.org/10.4102/hts.v63i3.240

Massarova, A. \& Potapenko, M., 2018, 'Approaches to poverty measurement in BRICS: A reflection on economic reality (the case of Brazil, China and Russia)', Bulletin of Geography 42(42), 183-194. https://doi.org/10.2478/bog-2018-0038

Merlo, J., 2014, The role of the BRICS in changing global governance: A case study of the post-2015 development negotiations, Center on International Cooperation, New York University, New York, NY.

Mutenga, M., 2021, 'The national economic policy framework to promote socioeconomic development in Zimbabwe', Unpublished $\mathrm{PhD}$, University of Johannesburg, Johannesburg.

Ngonyama, L.G., 2013, 'An exploration of the survival strategies of the poor in the Makause community in Primrose (Germiston), Ekurhuleni Metropolitan Municipality', Unpublished dissertation, University of KwaZulu-Natal, Durban.

Nhlapo, T.M.S., 2020, 'Human resource development strategy for gender equality within the Department of Correctional Services', Unpublished PhD, University of Johannesburg, Johannesburg.

Nkibrics.ru., 2019, The uncertain sustainability of BRICS strategies for sustainable development, viewed 16 March 2020, from http://www.nkibrics.ru/posts/show/ 5 cfa4f8e6272692ee0100000.

Nyikadzino, T. \& Vyas-Doorgapersad, S., 2020, 'Understanding the impact of devolutionary reforms on poverty reduction in Zimbabwean rural local authorities', Loyola Journal of Social Sciences XXXIV(1), 29-48. 
Overbeek, H., Dingwerth, K., Pattberg, P. \& Compagnon, D., 2010, 'Forum: Global governance: Decline or maturation of an academic concept?', International Studies Review 12(4), 696-719. https://doi.org/10.1111/j.1468-2486.2010.00967.x

Pelchem, 2021, BRICS introduction, viewed 12 July 2021, from https://www.pelchem. com/index.php/about-us/news/item/9-brics-introduction.

Røen, T.A., 2011, 'Changes in global governance: The case of the G20', Unpublished M dissertation, University of Stellenbosch, Stellebosch.

Scott, A.C., Bohl, D.K., Hedden, S., Moyer, J.D. \& Hughes, B.B., 2017, Sustainable development goals report: Brazil 2030, Development Programme Bureau for Policy Programme Support, New York, NY.

SDG Compass, 2015, Learn more about the SDGs, viewed 19 March 2020, from https://sdgcompass.org/sdgs/.

SDG Tracker, 2018, Sustainable development goal 1, viewed 13 July 2021, from https://sdg-tracker.org.

Social Watch, 2020, Utopia or Dystopia? The sustainable development goals in Brazil and in the world, Social Watch Secretariat, Montevideo.

South African Institute of International Affairs (SAllA), 2007, Emerging powers seek global economic governance reform, SAllA, Johannesburg.

Statistics South Africa, 2019, Five facts about poverty in South Africa, Statistics SA, Pretoria.

The Balance, 2020, India's economy, its challenges, opportunities, and impact, The Balance Secretariat, New York, NY.

The Borgen Project, 2018, What you should know: Top 10 facts about poverty in China, viewed 16 July 2020, from https://borgenproject.org/top-10-facts-about-povertyin-china/.

The Borgen Project, 2020, The BRICS summit 2017, viewed 03 March 2021, from https://borgenproject.org/brics-summit/.

The Heritage Foundation, 2020a, Brazil, viewed 17 February 2021, from https://www. heritage.org/index/country/brazil.

The Heritage Foundation, 2020b, South Africa, viewed 17 February 2021, from https://www.heritage.org/index/country/southafrica.

The Moscow Times, 2020, Putin's spending boost won't be enough to lift Russians out of poverty, audit chamber warns, viewed 16 August 2020, from https://www. themoscowtimes.com/2020/03/04/.

Ugoani, J.N.N., 2015, 'Global governance and poverty reduction through millennium development goals: Some regional experiences', Independent Journal of Management \& Production 6(4), 991-1017. https://doi.org/10.14807/ijmp.v6i4.348

UN India, 2020, SDG 1, viewed 17 June 2020, from https://in.one.un.org/page/ sustainable-development-goals/sdg-1/.
United Nations (UN), 2017, Voluntary national review 2017, UN, New York, NY. United Nations (UN), 2018, Sustainable development goals, UN, New York, NY. United Nations (UN), 2020, Voluntary national review 2020, UN, New York, NY. United Nations Development Programme (UNDP), 2012, About South Africa, viewed 05 March 2020, from http://www.za.undp.org/content/south_africa/en/home/ countryinfo/

United Nations Development Programme (UNDP), 2014, About South Africa, UNDP, South Africa.

UN SDG Knowledge Platform, 2020, Progress of goal 1 in 2019, UN, New York, NY.

Vyas-Doorgapersad, S., 2018, 'Designing measurement instruments for sustainable development goals one, five and nine: A gendered perspective in South Africa', African Journal of Public Affairs 10(3), 118-133.

Vyas-Doorgapersad, S., 2021, 'Role of BRICS in global governance to promote economic development', Unpublished manuscript.

Vyas-Doorgapersad, S. \& Ababio, E.P., 2010, 'The illusion of ethics for good local governance in South Africa', The Journal for Transdisciplinary Research in Southern governance in South Africa', The Journal for Transdisciplinary
Africa 6(2), 411-427. https://doi.org/10.4102/td.v6i2.273

Vyas-Doorgapersad, S. \& Aktan, C.C., 2017, 'Changing world and changing state: Rethinking the roles of the state', International Journal of Social Sciences and Humanities Studies 9(2), 80-94.

Weiping, T., 2018, Chinese approach to the eradication of poverty: Taking targeted measures to lift people out of poverty: A speech at the Expert Panel on the implementation of the third UN decade for the eradication of poverty (2018-2027), viewed n.d., from https:// www.un.org/development/desa/dspd/wp-content/uploads/sites/22/2018/05/15.pdf

World Bank, 2016, Understanding China's poverty reduction success to benefit the Global South, World Bank, New York, NY.

World Bank, 2019a, Russia economic report, World Bank, Washington, DC.

World Bank, 2019b, Weaker global outlook sharpens focus on domestic reforms, World Bank, Washington, DC.

World Bank, 2020, Overview, viewed 17 July 2020, from https://www.worldbank.org/ en/country/brazil/overview.

World Population Review, 2020, South Africa population 2021, viewed 12 March 2021 from https://worldpopulationreview.com/countries/south-africa-population.

World Vision, 2020, Global poverty: Facts, faqs, and how to help, viewed 17 July 2020, from https://www.worldvision.org/sponsorship-news-stories/global-poverty-facts.

Zhu, I., Yan, W, Zhu, L. \& Liu, J., 2021, 'Covid-19 pandemic in BRICS countries and its association with socio-economic and demographic characteristics, health vulnerability, resources, and policy response', Infectious Diseases of Poverty 10 97. https://doi.org/10.1186/s40249-021-00881-w 